\title{
S26
}

\section{Sequence Stratigraphy and Reservoir Characterization of the Lower Devonian in the Southwest of Algeria}

\author{
E. Figari* (Repsol YPF), J.M. Jáuregui (Repsol YPF), J. Gerard (Repsol YPF), \\ S. Adrianto (Repsol YPF), H. Abdallah (Repsol YPF), F. Djettou (Sonatrach), \\ R. Afrazmanech (Repsol YPF), T. Castro (Repsol YPF) \& C. Sakher (Repsol \\ YPF)
}

\section{SUMMARY}

Lower Devonian reservoirs in Southwest Algeria are included in a stratigraphic interval between the so called Caledonian Unconformity, at the Silurian/Devonian (Lochkovian) limit, and a major regional flooding surface at the Emsian top.

Three lithostratigraphic units are identified and correlated over hundreds of kilometers in outcrops and through Reggane basin. The Lochkovian/Gedinnian A \& B reservoir units have been respectively deposited in tidal and foreshore environment. The Pragian/Siegenian C \& D and Emsian reservoir units correspond to shoreface sandstones separated by offshore shales. In terms of sequence stratigraphy framework, they are equivalent to five 3rd Order Sequences (Vail et al., 1978), called De 1, 2, 34 and 5. A progressive decrease of the sand-shale ratio is expected from the SE to the NW of Reggane basin in every reservoir unit according to the overall progradation of the system and increasing marine influences. In spite of the extremely good correlation of these units around the whole area, internal heterogeneities exist due to facies associations and additional diagenetic processes. 


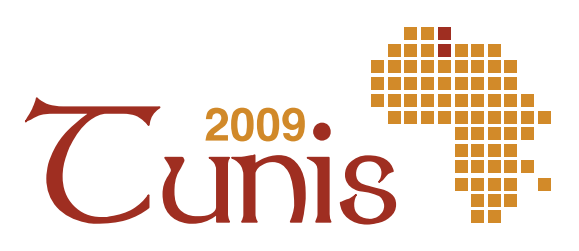

\section{Introduction}

The present study provides not only an integrated stratigraphy of the Lower Devonian in Southwest Algeria (Reggane and Ahnet basins), but also is an attempt to characterize the nature and the evolution of the main reservoirs in this area. The stratigraphic limit between Silurian and Devonian series corresponds to the so called "Caledonian Unconformity". This erosive surface is easily identified in outcrops and wells by the sharp contact between the marine Upper Silurian and the fluvial Lower Devonian sediments, but more difficult in seismic, because only related to a subtle basin slope change. Lower Devonian comprises the Lochkovian, Pragian and Emsian stages (Gedinnian, Siegenian and Emsian in local equivalent denominations), units that never have been dated with detail in proximal areas while the reliable dating has been found only in open marine equivalent facies.

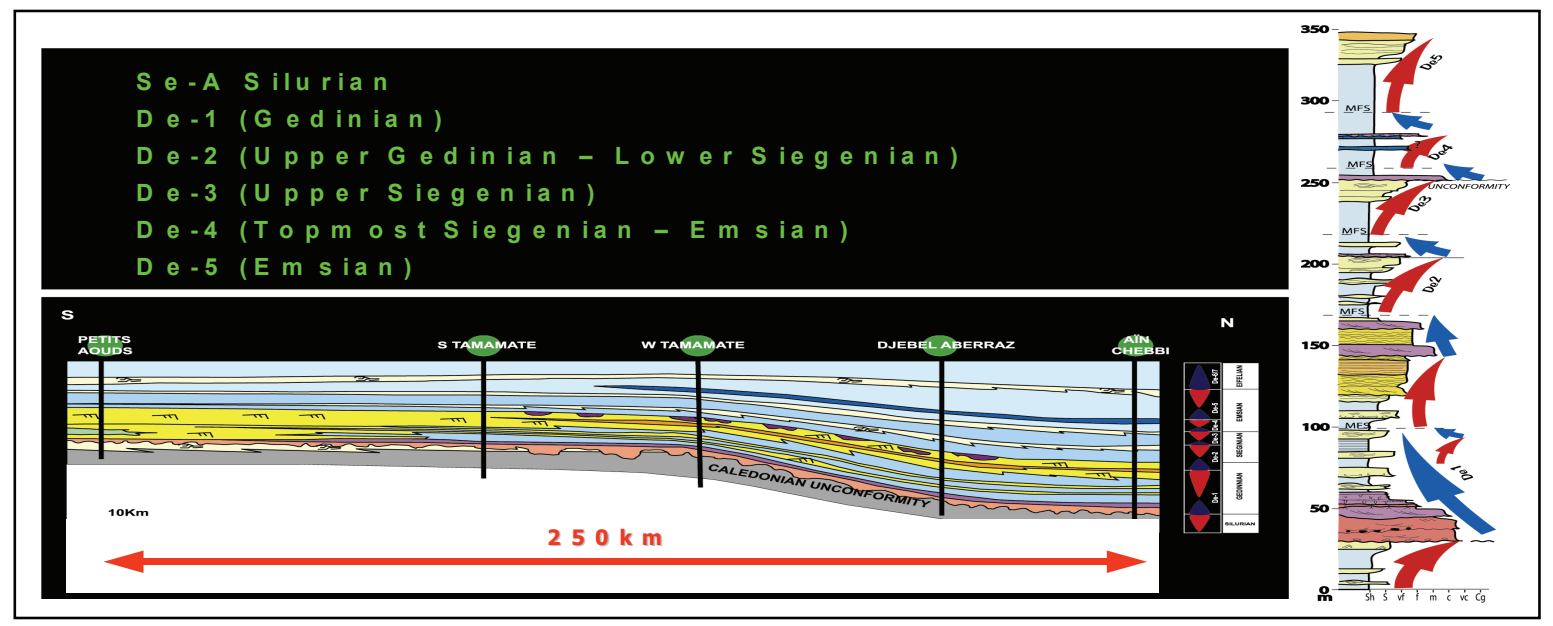

The lowest sandstone, also named Gedinnian $\mathbf{A}$, is limited by a sharp erosional surface showing channel incisions and truncating the Upper Silurian marine sediments. Very coarsegrained sandstones deposited in fluvial channels overlay this surface. Medium- to coarsegrained sandstones with bioturbation, deposited in estuarine environments, are in the top of the basal fluvial facies. A mud-prone succession is overlaying the previous levels, which is organized in a fining upward and then a coarsening upward trend where the upper part is progressively passing to a sandstone unit called Gedinnian B. Fining upward trend sandstone beds first display evidences of tidal reworking, and then hummocky cross-stratification testifies of storm wave action in a progressively deepening upward environment ending with a silty mudstone section, thinly laminated, deposited in a lower offshore environment. The upper Gedinnian sandstone (Ged B) unit, which is around $40 \mathrm{~m}$ thick in section, consists of fine- to very coarse-grained sandstones with ripple bedding, sigmoidal, swaley and low-angle cross-bedding. These sediments form a coarsening and shallowing upward prograding sequence from subtidal to foreshore environment.

The second lithostratigraphic unit (Pragian/ Siegenian) corresponds to $80-90 \mathrm{~m}$ of marine mudstones alternating with shoreface and tidal sandstone levels. The base of this unit is a transgressive surface that makes a sharp bioturbated surface on top of the Gedinnian B. Above, marine silty shales are interbedded with HCS sandstone beds associated to a lumachella level extremely rich in fossils (Brachiopods, crinoids, etc.) defining a shallowing upward arrangement. The sandy unit has also been called Siegenian C. The lumachella is overlaid by offshore shales and then shoreface sandstones that form a second shallowing upward cycle called Siegenian D. In some subsurface areas, very coarse-grained to conglomerate sandstones can be observed on top. An unconformity may exist at this level to explain this abnormal succession. 
The last lithostratigraphic unit (Emsian) corresponds to a shale-rich unit around 100 $\mathrm{m}$ thickness. The lower half unit displays thin fossil-rich (brachiopods, crinoids and corals) carbonate levels interbedded with offshore shales, whereas the upper half shows a coarsening upward sequence of shoreface sediments.

\section{Sequence Stratigraphy}

Five 3rd Order Sequences (Vail et al., 1978) can be defined in the Lower Devonian section. They have been called in this work De 1, 2, 34 and 5 that partially coincided with the Ged A, Ged B, Sieg C, Sieg D and Emsian. Main differences come from the fact that sequence boundaries are recognized for major facies shifting, inclusively inside the lithozone, and that the MFS of each sequence is the main condensed horizon and/or the most pronounced marine influence level in the vertical column. Internally, parasequences can also be correlated over kilometers. The most relevant sequence boundaries are located in the bottom of De 1 (Caledonian unconformity) where incised valley figures appear, and in the bottom of Couvinian (top of De 5) a regional erosive flooding surface. The whole Lower Devonian section, with a thinning and fining upward arrangement, represents a Sequence Set, belonging to a clear sea level rise during this period with a reduction in the accommodation space.

\section{Reservoir Characterization}

A progressive decrease of the sand-shale ratio is expected from the SE to the NW of Reggane basin in every reservoir unit according to the overall progradation of the system and increasing marine influences. The offshore shales are separating most of the different reservoir/flow units (lithozones) but are also creating permeability barriers of regional extension. In spite of the extremely good correlation of these units around the whole area, they have internal heterogeneities due to facies associations and additional diagenesis processes. The best reservoirs are clean sandstones where carbonate cements are absent and radial pore lining chlorite has inhibited quartz overgrowth formation. They represent channels and bars, in one large estuarine environment, surrounded by tight overbank deposits. The final product is a complex system of "pipes" and "tankers" where is possible to get from a few thousands of $\mathrm{m}^{3} / \mathrm{d}$ to more than $1.5 \mathrm{MMm}^{3} / \mathrm{d}$ of dry gas. A Regional Petrel Stratigraphic Modeling, seismic attributes, lab studies and hydraulic fracturing are being performed to enhance this behavior and to reduce the risk. 